\title{
1. INTRODUCTION: SCIENTIFIC OBJECTIVES AND EXPLANATORY NOTES ${ }^{1}$
}

\author{
Shipboard Scientific Party ${ }^{2}$
}

Plate tectonics has raised a number of new and intriguing questions, especially concerning subduction complexes, subduction mechanics, and evolution of subduction zones (Fig. 1). Answering these questions has been difficult, owing in part to the problem of studying active subduction complexes. Seismic reflection investigations have been frustrated by the complex structures of subduction complexes, and Deep Sea Drilling Project efforts to sample subduction complexes have been similarly frustrated by thick hemipelagic slope apron deposits that limit penetration into the deformed rocks and sediments. Leg 66 was part of a broader effort to overcome these difficulties and contribute to the resolution of critical questions about subduction.

Leg 66 is actually part of two broader investigations of subduction complexes and convergent margin geology-one led by the Active Margin Panel (AMP) of the International Phase of Ocean Drilling (IPOD) to drill selected convergent margins to elucidate structure and evolution and the other, led by the University of Texas Marine Science Institute's (UTMSI) Galveston Geophysical Laboratory (GGL) to investigate the tectonics of the Middle America Trench from the Cocos Fracture Zone to the Riviera Fracture Zone. The synergism of these two efforts resulted in the drilling of Legs 66 and 67 off southwestern Mexico and Guatemala, respectively. The present volume and Volume 67 (von Huene et al., in press) are thus companion efforts.

The reason for investigating two adjacent areas derives from their contrast in tectonic framework. It appears that much if not all of the Paleogene(?) and Mesozoic subduction complex off southwestern Mexico is missing, whereas the Guatemala subduction complex is normal in outcrop, seismic, and bathymetric data. We hoped that comparative studies of the two regions

\footnotetext{
1 Initial Reports of the Deep Sea Drilling Project, Volume 66.

2 Joel S. Watkins (Co-Chief Scientist), Gulf Research and Development Company, Houston, Texas (present address: Geology and Interpretation Department, Exploration and Production Division, Gulf Science and Technology Company, Pittsburgh, Pennsylvania); J. Casey Moore (Co-Chief Scientist), Earth Sciences Board, University of California, Santa Cruz, California; Steven B. Bachman, Department of Geology, University of California, Davis, California (present address: Department of Geological Sciences, Cornell University, Ithaca, New York); Floyd W. Beghtel, Phillips Petroleum Company, Bartlesville, Oklahoma; Arif Butt, Institut und Museum für Geologie und Paläontologie, Universität Tübingen, Tübingen, Federal Republic of Germany; Borys M. Didyk, Research and Development Laboratory, Empresa Nacional del Petróleo (ENAP), Concon, Chile; Glen Foss, Deep Sea Drilling Project, Scripps Institution of Oceanog Drect, Scripps Intiontion, Kingdom; Neil Lundberg, Earth Sciences Board, University of California, Santa Cruz, California; Kenneth J. McMillen, Geophysics Laboratory, Marine Science Institute, University of Texas, Galveston, Texas (present address: Geology and Interpretation Department, Exploration and Production Division, Gulf Science and Technology Company, Pittsburgh, Pennsylvania): Nobuaki Niitsuma, Institute of Geosciences, Shizuoka University, Oya, Shizuoka, Japan; Les E. Shephard, Department of Oceanography, College of Geosciences, Texas A\&M University (present address: Sandia National Laboratories Division 4536, Albuquerque, New Mexico), College Station, Texas; Jean-François Stephan, Département de Géotectonique, Université Pierre et Marie Curie, Paris, France; Thomas H. Shipley, Scripps Institution of Oceanography. University of California at San Dicgo, La Jolla, California; and Herbert Stradner, Geologische Bundesanstalt, Vienna, Austria,
}

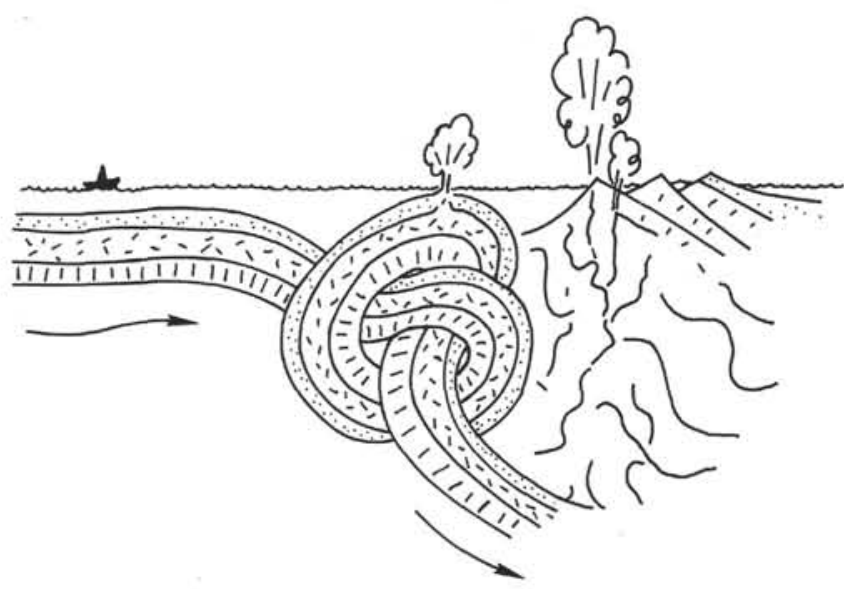

Figure 1. The complexity of active margins may not as yet be fully appreciated by earth scientists.

would yield insights greater than those derived from studies of either region alone.

\section{ACCRETION}

Much of the predrilling debate about the Legs 66-67 areas focused on the relative roles of accretion and tectonic erosion, with accretion the favored mechanism for the formation of the Guatemala subduction complex and subduction erosion the favored mechanism for the southwestern Mexico margin.

The concept of accretion evolved during the late 1960 s and early 1970s. Seyfert (1969) first pointed out that accretion-related deformation of trench sediments could explain the abrupt disappearance of seismic reflectors at the foot of the slope in seismic traverses across turbidite-filled trenches and inner trench walls. Dickinson (1971) suggested that although ocean basement is carried down with the descending lithosphere, lighter sediments probably are scraped off against the overriding plate. Offscraped sediments and ophiolitic scraps presumably combine to form mélanges.

Von Huene (1972), with improved seismic reflection data, observed ocean crust and overlying undeformed pelagic sediments extending up to $12 \mathrm{~km}$ landward of the Aleutian Trench beneath deformed slope sediments. Although thrust faults were not clearly evident in the slope seismic data, von Huene's interpretation suggested their existence. Dickinson (1973) strengthened the argument for accretion with the observation that, with few exceptions, widths of arc-trench gaps are proportional to the age of the island arc-trench system-a result, he theorized, of the steady accretion of crustal materials by the inner wall. DSDP Leg 31 drilled the toe 
of the slope landward of the Japan Trench off the island of Shikoku in mid-1973. Cores showed that Pleistocene trench sediments had been compressed to about half their original volume and given a distinct cleavage within $6 \mathrm{~km}$ of the trench. Elevation of these sediments to 300 meters above the trench floor (Karig et al., 1975), provided further evidence of accretion.

Seely et al. (1974) integrated the foregoing observations in their interpretation of multifold, commondepth-point seismic reflection data collected off Guatemala and Oregon, inferring that older, upper mélange slices were scraped off, then rotated upward as younger slices were progressively emplaced by underthrusting.

\section{SUBDUCTION EROSION}

Not all old trench systems have wide arc-trench gaps, and some appear to have anomalously small subduction complexes. Where is the material that originally comprised these gaps? And why were there no subduction complexes? Subduction erosion has been suggested as the answer.

Hussong et al. (1976) investigated an example in the Peru-Chile trench between $8^{\circ}$ and $12^{\circ} \mathrm{S}$ latitude. Here, volcanic studies on land show evidence of subduction as old as mid-Mesozoic, but multifold seismic reflection and detailed seismic refraction studies suggest a narrow $(10-\mathrm{km})$ subduction complex comprised of low-velocity apron of undeformed sediments underlain by rocks and velocities of $5 \mathrm{~km} / \mathrm{s}$, the latter more consistent with continental metaigneous rock velocities than with those of deformed trench turbidites. Hussong and his colleagues interpret these data as indicating that not only are sediments being subducted but the subduction process is eroding the leading edge and underside of the continental crust and subducting continental crust.

In some respects, the Mexico margin in the Leg 66 area resembles the Peru-Chile margin. Land studies suggest that lower Tertiary and Cretaceous volcanic arcs lay much closer to the trench than does the present volcanic axis. As in the case of the Peru-Chile Trench, seismic reflection data suggest an anomalously narrow subduction complex, considering the probable age of the subduction. Creighton Burk, a leading proponent of active margin research in the 1970 s, was to my knowledge the first to suggest that subduction erosion might be responsible for the missing elements of the Mexican subduction complex (personal communication, 1975).

\section{SEDIMENT CONSUMPTION}

Earlier investigations, although providing abundant evidence of accretion, did not preclude subduction of a significant fraction of the pelagic-hemipelagic-turbidite flux. Von Huene (personal communication, 1980) noted that calculations suggest subduction of a significant fraction of the sedimentary input into the Alaskan and Japan trenches, and Karig and Sharman (1975) in their review of the accretionary mechanism suggest that some of the sedimentary cover may reach considerable depths before shearing off. Thus it was proposed to attempt to quantify sediment consumption off southwestern Mexico as well as to investigate accretion, subduction mechanics, and subduction erosion.

\section{HISTORY}

The AMP proposed investigation of the Middle America Trench at the initial IPOD panel meetings in Orangeburg, New York, 22-25 October, 1974, and refined their objectives at a meeting in La Jolla, California, 28 April-1 May, 1975, to read:

\footnotetext{
“"Three deep holes are proposed near $12^{\circ} 20^{\prime} \mathrm{N}$ off Guatemala across this accretionary trench in order to investigate evidence for and against episodic subduction, the nature of the thrust material, and the mode of slope accretion.

"Two shallow holes are also proposed off Mexico at $18^{\circ} \mathrm{N}$ to investigate the formational processes of the trench."
}

These objectives were subsequently enlarged to comprise transects across each margin.

The AMP meeting in April 1976 assigned first priority to drilling in the Middle America Trench, Kuriles, Japan Trench, Philippine Sea, and Sea of Okhotsk.

The University of Texas Marine Science Institute's Galveston Geophysical Laboratory undertook the site surveys of Legs 66 and 67 during 1976 and 1977. Coincidentally, GGL Director J. Lamar Worzel, together with John Heacock, had named the Middle America Trench in 1955. The site surveys concentrated in areas off southern Mexico and Guatemala where additional information-notably Exxon seismic data (Seely et al., 1974), Scripps refraction data (Shor and Fisher, 1961), and Hawaii-Wisconsin refraction data (Helsley et al., 1975; Mooney et al., 1975) - were available. These surveys contributed significantly to the success of Leg 66 . The discovery and delineation of a relatively small zone of landward-dipping reflectors from the seismic data, dredge hauls of metaigneous rocks from a canyon within the Leg 66 area, numerous cores, and, most important, detailed seismic reflection coverage made possible the precise targeting of sedimentary and tectonic structures for investigation by the drill.

\section{EXPLANATORY NOTES}

Leg 66 departed Mazatlàn, Mexico on 18 March 1979 and arrived in Manzanillo, Mexico on 2 May 1979. Eight sites were drilled along a transect in water depths that ranged from 645 to 5142 meters (Figs. 2 and 3; Table 1).

\section{Authorship}

Authorship of the eight site chapters includes the complete Scientific Party, with one of the two co-chief scientists the primary author. Ultimate responsibility lies with the co-chief scientists. Within the site chapters the assigned responsibilities are as follows:

Site Summary Data and Principal Results (Watkins, Moore, and Shipley)

Background and Objectives (Moore [486, 488, 491, 492]; Watkins [487, 489, 490, 493])

Operations (Foss)

Lithologic Summary (Bachman [489, 493]; Leggett

[486, 490]; Lundberg [488, 492]; Stephan [487, 491])

Biostratigraphy (McMillen, Stradner, Butt)

Sediment Accumulation Rates (McMillen)

Paleobathymetry (McMillen and Shephard)

Paleomagnetism (Niitsuma) 


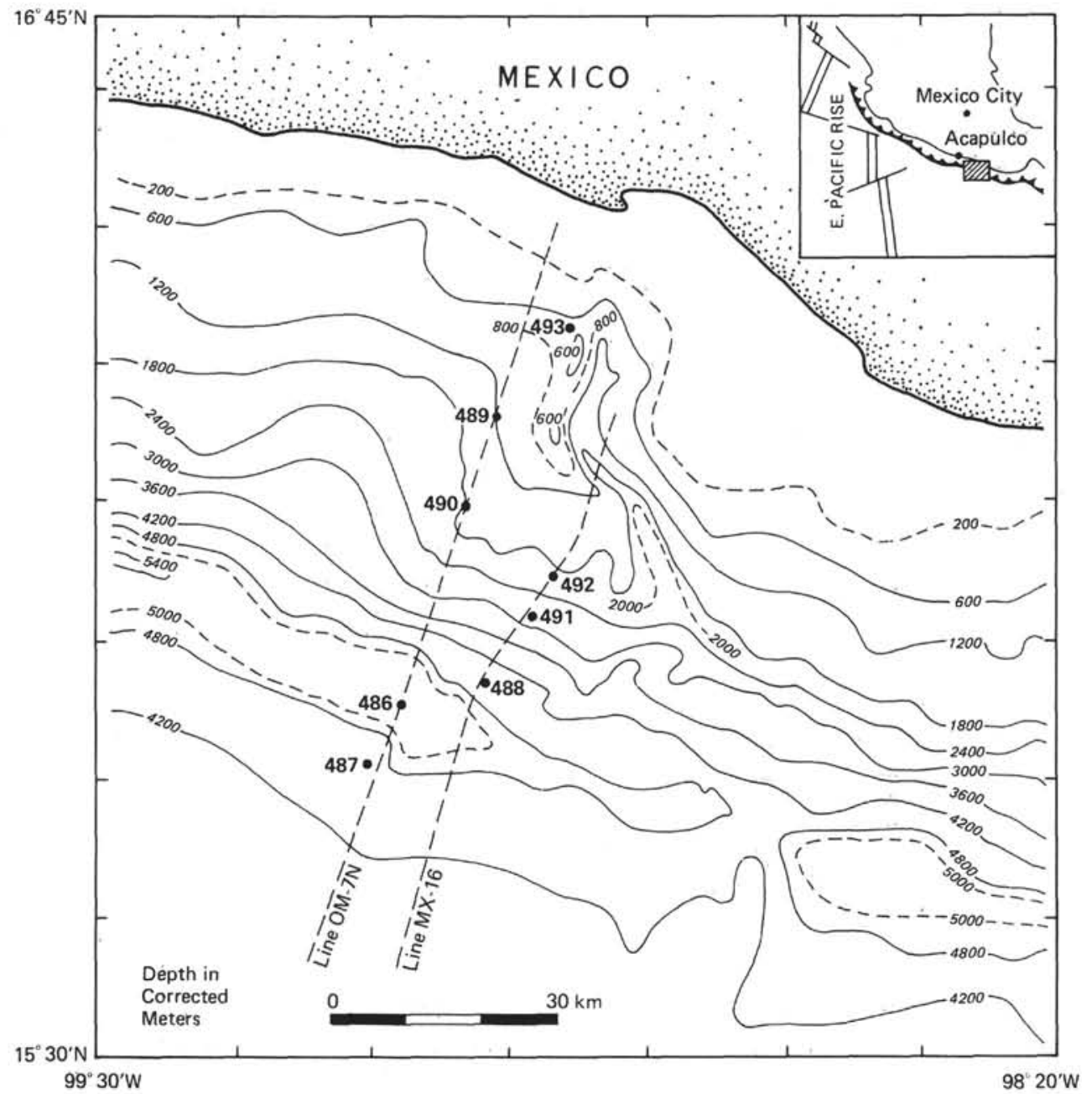

Figure 2. Location of Leg 66 sites.

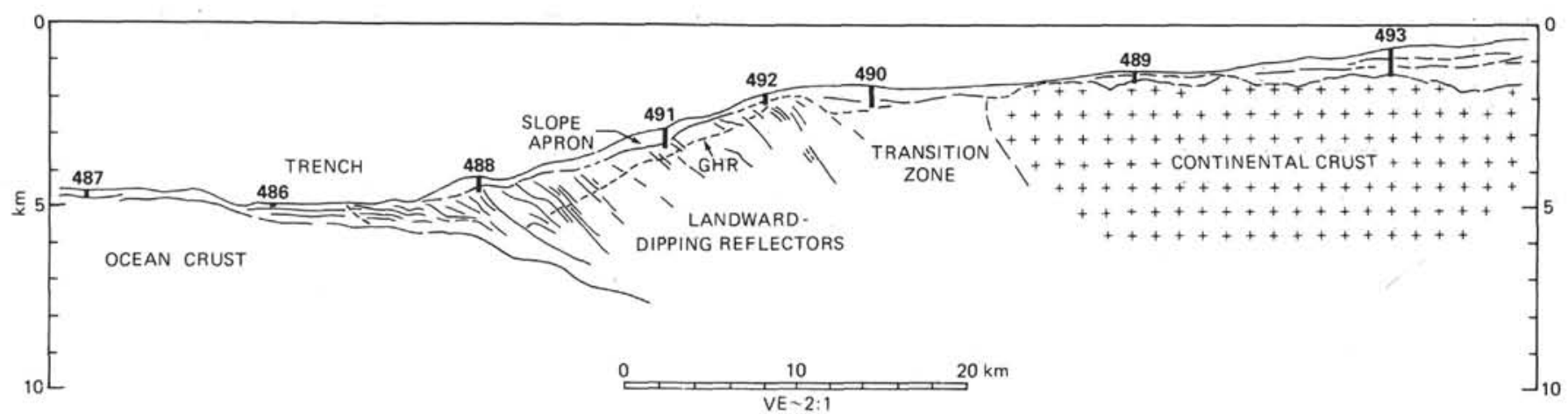

Figure 3. Schematic cross section through Leg 66 drill sites.

Organic Geochemistry (Didyk and Beghtel) Physical Properties (Shephard)

Inhole Temperature Measurements (Shipley) Igneous Petrography (Lundberg and Stephan) Correlation of Seismic Reflection and Drilling Results (Shipley)

Summary and Conclusions (Moore [486, 488, 491, 492]; Watkins [487, 489, 490, 493])

\section{Numbering of Sites, Holes, Cores, and Samples}

DSDP drill sites are numbered consecutively from the first site drilled by Glomar Challenger in 1968. Site numbers are slightly different from hole numbers. A site number refers to one or more holes drilled while the ship was positioned over one acoustic beacon. These holes may be located within a radius as great as 900 meters 
Table 1. Leg 66 coring summary.

\begin{tabular}{|c|c|c|c|c|c|c|c|c|c|}
\hline Hole & $\begin{array}{l}\text { Dates } \\
\text { (1979) }\end{array}$ & Latitude & Longitude & $\begin{array}{l}\text { Water } \\
\text { Depth } \\
\text { (m) }\end{array}$ & $\begin{array}{l}\text { Penetration } \\
\text { (m) }\end{array}$ & $\begin{array}{c}\text { Number } \\
\text { of } \\
\text { Cores }\end{array}$ & $\begin{array}{l}\text { Coring } \\
\text { (m) }\end{array}$ & $\begin{array}{l}\text { Recovery } \\
\text { (m) }\end{array}$ & $\begin{array}{c}\text { Recovery } \\
(\%)\end{array}$ \\
\hline 486 & 22-23 March & $15^{\circ} 55.37^{\prime} \mathrm{N}$ & $99^{\circ} 08.10^{\prime} \mathrm{W}$ & 5142 & 38.0 & 5 & 38.0 & 12.5 & 33 \\
\hline $486 \mathrm{~A}$ & 23-24 March & $15^{\circ} 54.83^{\prime} \mathrm{N}$ & $99^{\circ} 08.28^{\prime} \mathrm{W}$ & 5138 & 22.0 & 3 & 22.0 & 3.5 & 16 \\
\hline 487 & 24-27 March & $15^{\circ} 51.21^{\circ} \mathrm{N}$ & $99^{\circ} 10.52^{\prime} \mathrm{W}$ & 4764 & 181.7 & 21 & 181.7 & 119.9 & 66 \\
\hline 488 & 27 March-2 April & $15^{\circ} 57.10^{\prime} \mathrm{N}$ & $99^{\circ} 01.66^{\prime} \mathrm{W}$ & 4254 & 428.5 & 46 & 428.5 & 160.4 & 37 \\
\hline 489 & 3-5 April & $16^{\circ} 16.19^{\prime} \mathrm{N}$ & $99^{\circ} 01.13^{\prime} \mathrm{W}$ & 1240 & 34.5 & 4 & 34.5 & 22.6 & 66 \\
\hline $489 \mathrm{~A}$ & 5-7 April & $16^{\circ} 16.19^{\prime} \mathrm{N}$ & $99^{\circ} 01.13^{\prime} \mathrm{W}$ & 1240 & 298.5 & 34 & 298.5 & 164.5 & 55 \\
\hline 490 & 8.13 April & $16^{\circ} 09.56^{\circ} \mathrm{N}$ & $99^{\circ} 03,39^{\prime} \mathrm{W}$ & 1761 & 588.5 & 64 & 588.5 & 344.8 & 59 \\
\hline 491 & 13-20 April & $16^{\circ} 01.74^{\prime} \mathrm{N}$ & $98^{\circ} 58.33^{\prime} \mathrm{W}$ & 2883 & 542.0 & 59 & 542.0 & 388.0 & 72 \\
\hline 492 & 20-23 April & $16^{\circ} 04.73^{\prime} \mathrm{N}$ & $98^{\circ} 56.72^{\prime} \mathrm{W}$ & 1935 & 279.0 & 31 & 279.0 & 189.6 & 68 \\
\hline $492 \mathrm{~A}$ & 23-24 April & $16^{\circ} 04.73^{\prime} \mathrm{N}$ & $98^{\circ} 56.72^{\prime} \mathrm{W}$ & 1935 & 71.8 & 11 & 51.8 & 30.3 & 59 \\
\hline $492 B$ & 29-30 April & $16^{\circ} 04.73^{\prime} \mathrm{N}$ & $98^{\circ} 56.72^{\prime} \mathrm{W}$ & 1942 & 290.0 & i & 9.5 & 6.4 & 68 \\
\hline 493 & 24-28 April & $16^{\circ} 22.86^{\prime} \mathrm{N}$ & $98^{\circ} 55.53^{\prime} \mathrm{W}$ & 645 & 670.5 & 60 & 556.5 & 333.4 & 60 \\
\hline $493 \mathrm{~A}$ & 28-28 April & $16^{\circ} 22.86^{\prime} \mathrm{N}$ & $98^{\circ} 55.53^{\prime} \mathrm{W}$ & 645 & 12.0 & 2 & 12 & 7.6 & 63 \\
\hline 493B & 28-29 April & $16^{\circ} 22.86^{\prime} \mathrm{N}$ & $98^{\circ} 55.53^{\prime} \mathrm{W}$ & 645 & 126.0 & 12 & 114 & 59.8 & 52 \\
\hline
\end{tabular}

${ }^{a}$ Corrected meters from echo sounding.

from the beacon. Several holes may be drilled at a single site by pulling the drill pipe above the seafloor (out of one hole), moving the ship 100 meters or more from the first hole, and drilling another hole.

The first (or only) hole drilled at a site takes the site number. A letter suffix distinguishes each additional hole at the same site. For example, the first hole takes only the site number, the second takes the site number with suffix $\mathrm{A}$, the third takes the site number with suffix $\mathrm{B}$, and so forth. It is important, for sampling purposes, to distinguish among the holes drilled at a site, since sediments or rocks recovered from different holes usually do not come from equivalent positions in the stratigraphic column.

The cored interval is measured in meters below the seafloor. The depth interval for each core is the distance between the depth below seafloor at which the coring operation began and the depth at which it ended. Each coring interval is generally 9.5 meters long, which is the nominal length of a core barrel; however, it may be shorter or, sometimes, slightly longer. "Cored intervals" are not necessarily adjacent to each other but may be separated by "drilled intervals." In soft sediment, the drill string can be "washed ahead" with the core barrel in place, without recovering sediment, by pumping water down the pipe at high pressure to wash the sediment out of the way of the bit and up the space between the drill pipe and wall of the hole. If thin hard rock layers are present, however, "spotty" sampling of these resistant layers within the washed interval may occur, resulting in a cored interval greater than 9.5 meters.

Cores taken from a hole are numbered serially from the top of the hole downward. Core numbers and their associated cored interval in meters below the seafloor are normally unique for each hole; problems may arise, however, if an interval is cored twice. When this occurs, the core number is assigned a suffix, such as " $\mathrm{S}$," for supplementary. In special cases, some cores may also have a letter designation: for example: $\mathrm{H}=$ " washed interval but recovered material in the core barrel."

Full recovery for a single core is normally 9.28 meters of sediment or rock, which is in a plastic linear $(6.6-\mathrm{cm}$ I.D.), plus about a 0.2 -meter-long sample (without a plastic liner) in the Core-Catcher. The Core-Catcher is a device at the bottom of the core barrel which prevents the cored sample from sliding out while the barrel is be- ing retrieved from the hole. The core is then cut into 1.5 -meter-long sections and numbered serially from the top of the core (Fig. 4). When we obtain full recovery, the sections are numbered from 1 through 7 , with the last section shorter than 1.5 meters. The Core-Catcher sample is below the last section when the core is described and is labeled Core-Catcher (CC); it is treated as a separate section.

In the case of partial recovery, the original stratigraphic position of the material in the cored interval is unknown. If the recovered material is contiguous, we assign the top to the top of the cored interval and number sections serially from the top, beginning with Section 1 (Fig. 4). There are as many sections as needed to accommodate the length of the recovered material. For example, 4 meters of material are divided into $3 \mathrm{sec}-$ tions: 2 upper sections each, 1.5 meters long, and a final lower section only 1.0 meter in length. If the material recovered is not contiguous, as determined by the shipboard scientists, then sections are divided and numbered serially as with contiguous material and gaps labeled as voids for sediments (Fig. 4) or marked by spacers for igneous rocks (see Igneous Rocks section).

Samples are designated by distance in centimeters from the top of each section to the top and bottom of the sample in that section. A full identification number for a sample consists of the following information:

Leg

Site

Hole

Core Number

Interval in centimeters from the top of section

For example, a sample identification number of 66 489A-9-3, 12-14 cm is interpreted as follows: $12-14 \mathrm{~cm}$ designates a sample taken at $12-14 \mathrm{~cm}$ from the top of Section 3 of Core 9, from the second hole drilled at Site 489 during Leg 66. A sample from the Core-Catcher of this core is designated as $66-489 \mathrm{~A}-9, \mathrm{CC}$.

\section{Handling of Cores}

A core is normally cut into 1.5 meter sections, sealed, and labeled, then brought into the core laboratory for processing. Gas analyses and continuous wet-bulk density determinations using the Gamma Ray Attenuation Porosity Evaluation (GRAPE) are made on selected sections before splitting the plastic liner. 


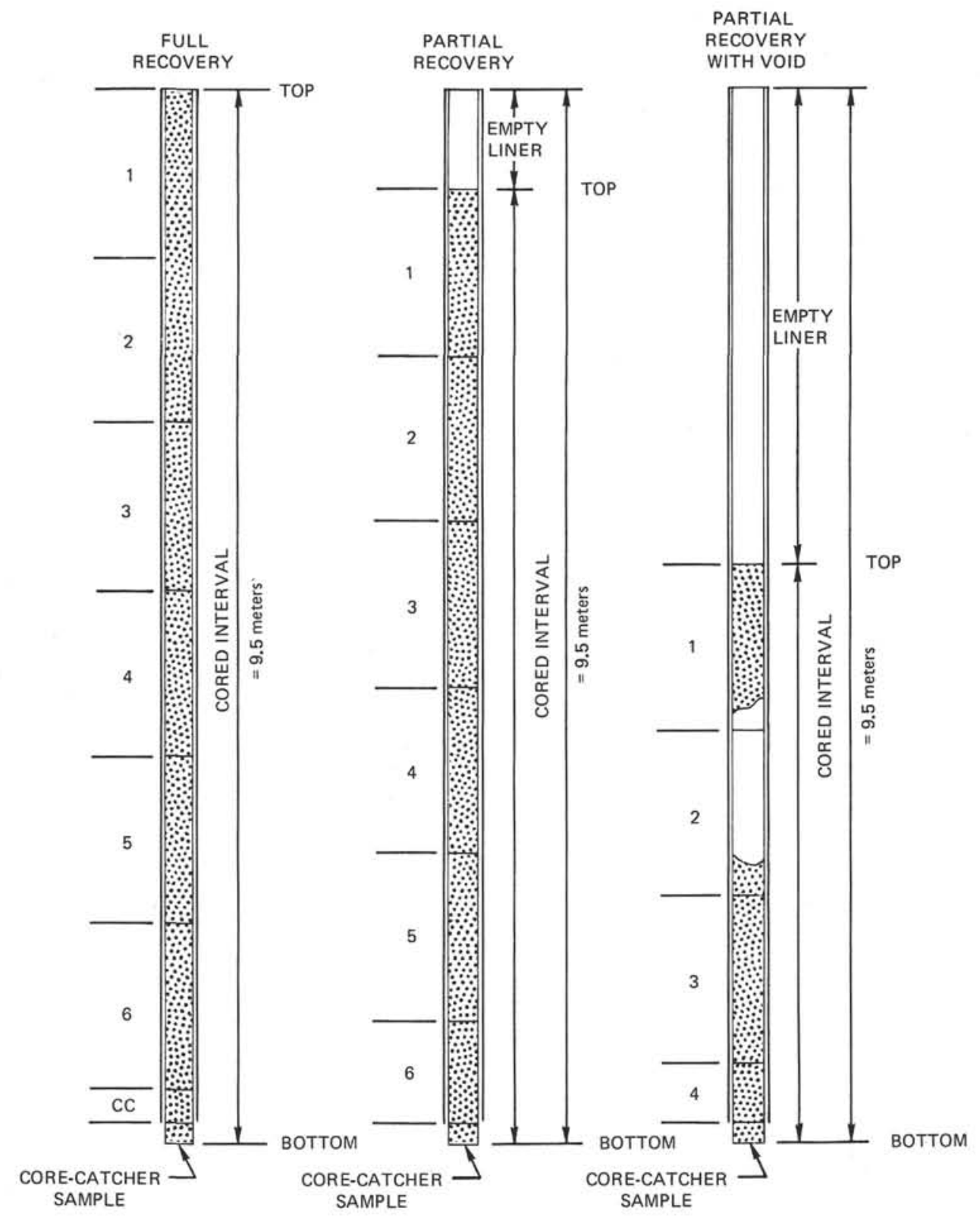

Figure 4. Diagram showing procedure in cutting and labeling of core sections.

The cores are then split longitudinally into "working" and "archive" halves. Samples are taken from the "working" half, including those for determination of grain-size distribution, mineralogy by $\mathrm{X}$-ray diffraction, sonic velocity by the Hamilton Frame method, wet-bulk density by a static GRAPE technique, water content by gravimetric analysis, carbon-carbonate analysis, calcium carbonate percentage (Karbonate Bomb), geochemical analysis, paleontological studies, and others.

Smear slides (thin sections for lithified sedimentary and igneous rocks) from each major lithology, and most minor lithologies, are prepared and examined microscopically. The archive half is then described and photographed. Physical disturbance by the drill bit, color, texture, structures, and composition of the various lithologies are noted on the standard core description forms.
All prime data are routinely microfilmed and some are digitized for computer retrieval.

After the cores are sampled and described, they are maintained in cold storage aboard Glomar Challenger until they can be transferred to the DSDP repository. Core sections of sediments removed for organic geochemistry study are frozen immediately onboard ship and kept frozen. All Leg 66 cores are presently stored at the DSDP West Coast Repository (Scripps Institution of Oceanography).

\section{HPC Cores}

On Leg 64 the Serocki-Storms-Cameron hydraulic piston corer (HPC) was first used successfully to recover undisturbed sediments at Site 480 and again at Site 481 . HPC holes are not assigned a special letter designation. 
The HPC operates on the principle of a 4.45 -meter core barrel which is lowered inside the drill string, hydraulically ejected into the sediment, and retrieved. The pipe is then lowered those 4.45 meters to the next interval and the procedure repeated. The HPC was used on Leg 66 at Hole 492A. High shear strengths in the Miocene sediments prevented good recovery with the HPC.

\section{PCB Cores}

Hole 491 was drilled with a special bit which cuts a core slightly smaller than the plastic core liner $(6.6-\mathrm{cm}$ I.D.). The bit was used to allow operation of a special pressure core barrel (PCB) to recover sediments at in situ pressure. On two attempts the PCB did not work correctly. Total recovery at Hole 491 was high (about $72 \%$ ), but the core was more highly disturbed by drilling than at similar holes using the normal diameter drill bit.

\section{Sediments and Sedimentary Rocks}

\section{Core Description Forms}

\section{Disturbance}

Recovered rocks, and particularly the soft sediments, may be extremely disturbed. This mechanical disturbance is the result of the coring technique, which uses a large $(25-\mathrm{cm}$ diameter) bit with a small $(6.0-\mathrm{cm}$ diameter) opening for the core sample. The following disturbance categories are used for soft and firm sediment: (1) Slightly deformed: Bedding contacts are slightly bent. (2) Moderately deformed: Bedding contacts have undergone extreme bowing. Firm sediment is fractured. (3) Very deformed: Bedding is completely disturbed or homogenized by drilling, sometimes showing symmetrical diapir-like structure. Firm zones may have relic "drill biscuits" in a breccia or homogeneous matrix. (4) Soupy: Water-saturated intervals which have lost all aspects of original bedding. (5) Breccia: Indurated sediments broken into angular fragments by the drilling process, perhaps along pre-existing fractures. These categories are coded on the core description form in the column headed "Drilling Disturbance" (Fig. 5).

\section{Sedimentary Structures}

In the soft, and even in some harder, sedimentary cores, it may be extremely difficult to distinguish between natural structures and structures created by the coring process. Thus the description of sedimentary structures was optional. Locations and types of structures appear as graphic symbols in the column headed "Sedimentary Structures" on the core description form (Fig. 5). Figures 6 and 7 give the keys to these symbols.

Bioturbation is difficult to recognize in the monotonous hemipelagic muds but are noted, where distinguishable, on the graphic column.

\section{Color}

Colors of the core samples are determined with a Geological Society of America Rock-Color Chart. Colors were determined immediately after the cores were split and while wet.

\section{Lithology}

The graphic column on the core description form is based on the lithologies and represented by a single pattern or by a grouping of two or more symbols. The symbols in a grouping correspond to end-members of sediment constituents, such as clay or nannofossil ooze. The symbol for the terrigenous constituent appears on the right-hand side of the column, the symbol for the biogenic constituent(s) on the left-hand side of the column. The abundance of any component approximately equals the percentage of the width of the graphic column its symbol occupies. For example the left $20 \%$ of the column may have a diatom ooze symbol, whereas the right $80 \%$ may have a silty-clay symbol, indicating sediment composed of $80 \%$ mud and $20 \%$ diatoms.

Because of the difference in the length-to-width ratio between the actual sediment core and the graphic lithologic column, it is not possible to reproduce structures as they appeared in the core; in the graphic representation they are highly flattened and distorted. The same is true for rock fragments or pebbles in the cores. As a result, the locations of pebbles are shown by a solid square and the depth of small "patches" of ash or other lithologic changes are given by triangular inset of the appropriate lithologic symbol on the right side of the lithologic column (Figs. 5 and 7). This convention applies also to beds thinner than $10 \mathrm{~cm}$. Voids less than 10 $\mathrm{cm}$ are not shown.

Smear slide (or thin section) compositions, carbonate content $\left(\% \mathrm{CaCO}_{3}\right)$, and organic carbon content determined onboard are listed below the core description; the two numbers separated by a hyphen refer to the section and centimeter interval, respectively, of the sample. The locations of these samples in the core and a key to the codes used to identify these samples are given in the column headed "Samples" (Fig. 5). Locations and intervals of organic geochemistry (OG), interstitial water (IW), and physical property (PP) samples are given in the lithology column.

\section{Lithologic Classification of Sediments}

The basic classification system used here was devised by the JOIDES Panel on Sedimentary Petrology and Physical Properties (SPPP) and adopted for use by the JOIDES Planning Committee in March 1974. Leg 66 shipboard scientists have modified this classification because of the dominant hemipelagic nature of the sediments recovered and difficulty in accurately determining silt/clay ratios in smear slides.

This classification is descriptive rather than generic, and divisions between different types of sediment are somewhat arbitrary. We treat lithologic types not covered in this classification as a separate category termed Special Rock Types. A brief outline of the conventions and descriptive data used to construct this classification follows (see Figs. 8 and 9). 


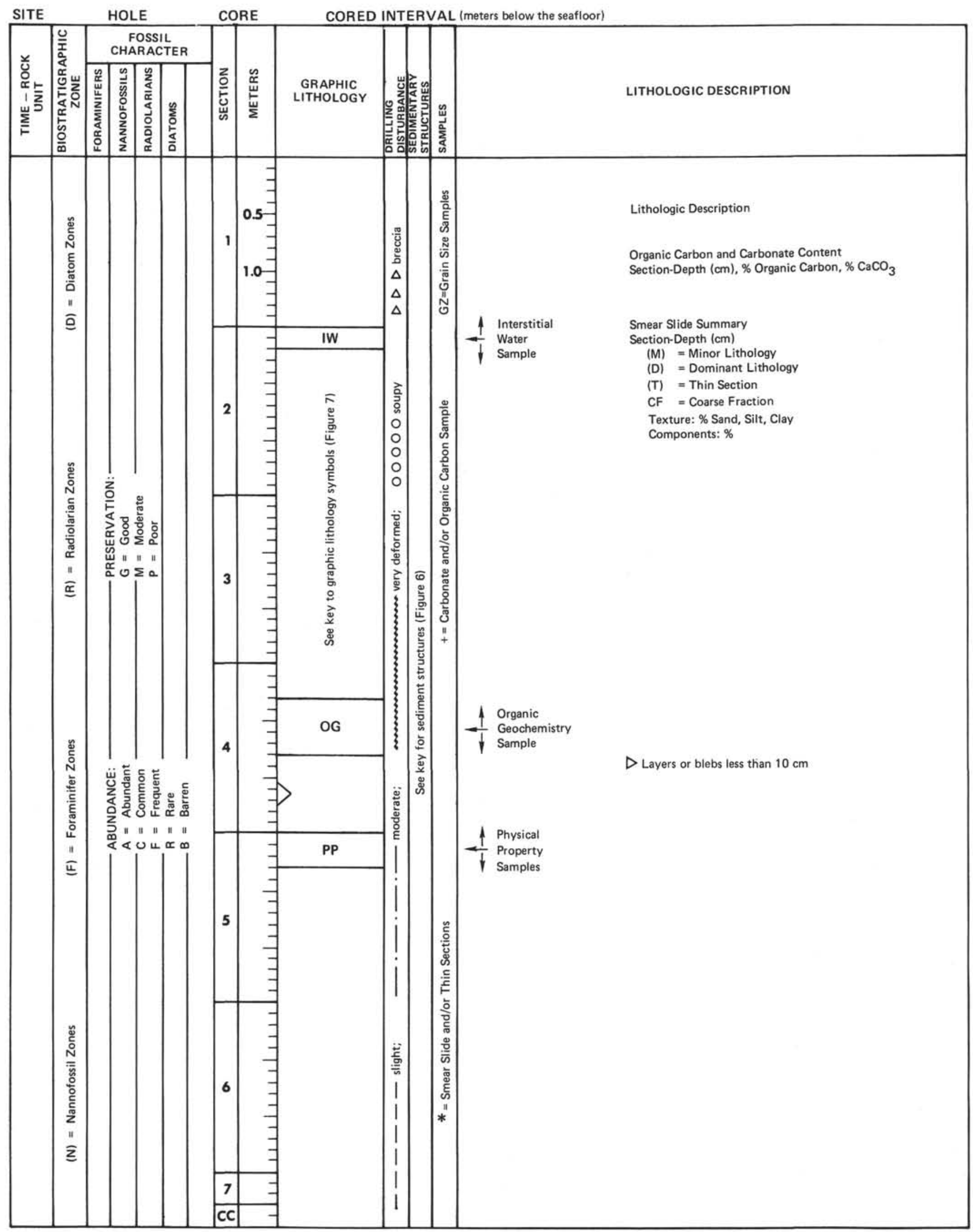

Figure 5. Sample core form (sediment). 


\begin{tabular}{|c|c|}
\hline 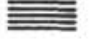 & Parallel bedding \\
\hline$\sim$ & Load casts \\
\hline & Plant or wood fragments \\
\hline 0 & Scour \\
\hline$\ddot{\cdots}$ & Normal graded bedding \\
\hline$\overline{\bullet \bullet}$ & Reversed graded bedding \\
\hline neev & Convolute and contorted bedding \\
\hline & Shell fragments \\
\hline--- & Gradational contact \\
\hline & Sharp contact \\
\hline गI & Zoophycos \\
\hline - & Teichichnus \\
\hline Q & Siliceous spong spicules \\
\hline 11$\rangle$ & Chondrites \\
\hline 4 & Interval over which a specific structure occurs in core \\
\hline 1 & Bioturbation - minor $(0-30 \%$ surface area) \\
\hline$\$ 1$ & Bioturbation - moderate $(30-60 \%$ surface area) \\
\hline III & Bioturbation - strong (more than $60 \%$ of surface area) \\
\hline 6050 & Burrows \\
\hline
\end{tabular}

Figure 6. Symbols of sedimentary structures used on core description forms (sediment).

\section{Conventions and Descriptive Data}

\section{Composition and Texture}

In this classification composition and texture are the only criteria used to define the type of sediment or sedimentary rock. Composition is more important for describing sediments deposited in the open ocean, and texture becomes significant for hemipelagic and nearshore sediments. These data come principally from visual estimates of smear slides using a petrographic microscope. They are estimates of areal abundance and size components on the slide and may differ somewhat from more accurate analyses of grain size, carbonate content, and mineralogy (see Special Studies section). From past experience, we find quantitative estimates of distinctive minor components to be accurate to within $1-2 \%$, but for major constituents accuracy is poorer, $\pm 10 \%$. All smear slide estimates were done onboard. At Site 487
(Cores 13-19), disparity between smear slides estimation of grain size and laboratory analysis appears to be much more than $10 \%$. After re-examination of the relevant smear slides on land, we preferred to use the visual estimation values. The large difference between methods may be due to floculation of clays during laboratory processing. Carbonate content is difficult to estimate from smear slides. Therefore, for many cores we determined the percentage of carbonate using the "Karbonate Bomb" technique of Müller and Gastner (1971), which treats a powdered sample with $\mathrm{HCl}$ in a closed cylinder. The resulting pressure of $\mathrm{CO}_{2}$ is proportional to the carbonate $\left(\mathrm{CaCO}_{3}\right)$ content of the sample, and this value is converted to percentage of $\mathrm{CaCO}_{3}$, using the calibration factor of the manometer. The accuracy of this method is $\pm 5 \%$. Carbonate content determined in this manner is listed on the core description forms below the lithologic description.

Where applicable we used one or several modifiers in naming the type of sediment encountered. In all cases the dominant component appears last in the name; minor components precede, with the least common constituent listed first. Minor constituents occurring in amounts less than $10 \%$ are not included in the name. This convention also holds for zeolites, $\mathrm{Fe}$ - and $\mathrm{Mn}$-micronodules, and other indicators of very slow rates of sedimentation or nondeposition, such as fish bones. Often these minerals are conspicuous even though greatly diluted. If deemed important and environmentally significant, as glauconite and dolomite were on Leg 64, they are sometimes included in the name of the sediment or mentioned in the lithologic description.

\section{Induration of Sediments}

We recognize three classes of induration or lithification for all sediments, differing slightly from previous legs.

1) Calcareous sediments and sedimentary rocks; categories after Gealy et al. (1971). (1) soft = ooze; has little strength and readily deformed under pressure of finger or broad blade of spatula; (2) firm = chalk; partially lithified and readily scratched with fingernail or edge of spatula; (3) hard = limestone, dolostone, well lithified and cemented, resistant or impossible to scratch with fingernail or edge of spatula.

2) The three classes of induration for transitional carbonates, siliceous, pelagic, and terrigenous sediments are as follows: (1) soft = sediment core may be split with wire cutter; (2) firm = partially lithified but finger-tip pressure leaves an indentation; (3) hard = cannot be compressed with finger-tip pressure.

\section{Types of Sediments and Compositional Boundaries}

\section{Pelagic Clay}

Pelagic clay is principally authigenic pelagic deposits that accumulate at very slow rates. The class has often been termed brown clay or red clay, but since these terms are confusing we did not use them.

1) Boundary of pelagic clay with terrigenous sediments is where authigenic components ( $\mathrm{Fe} / \mathrm{Mn}$ micro- 


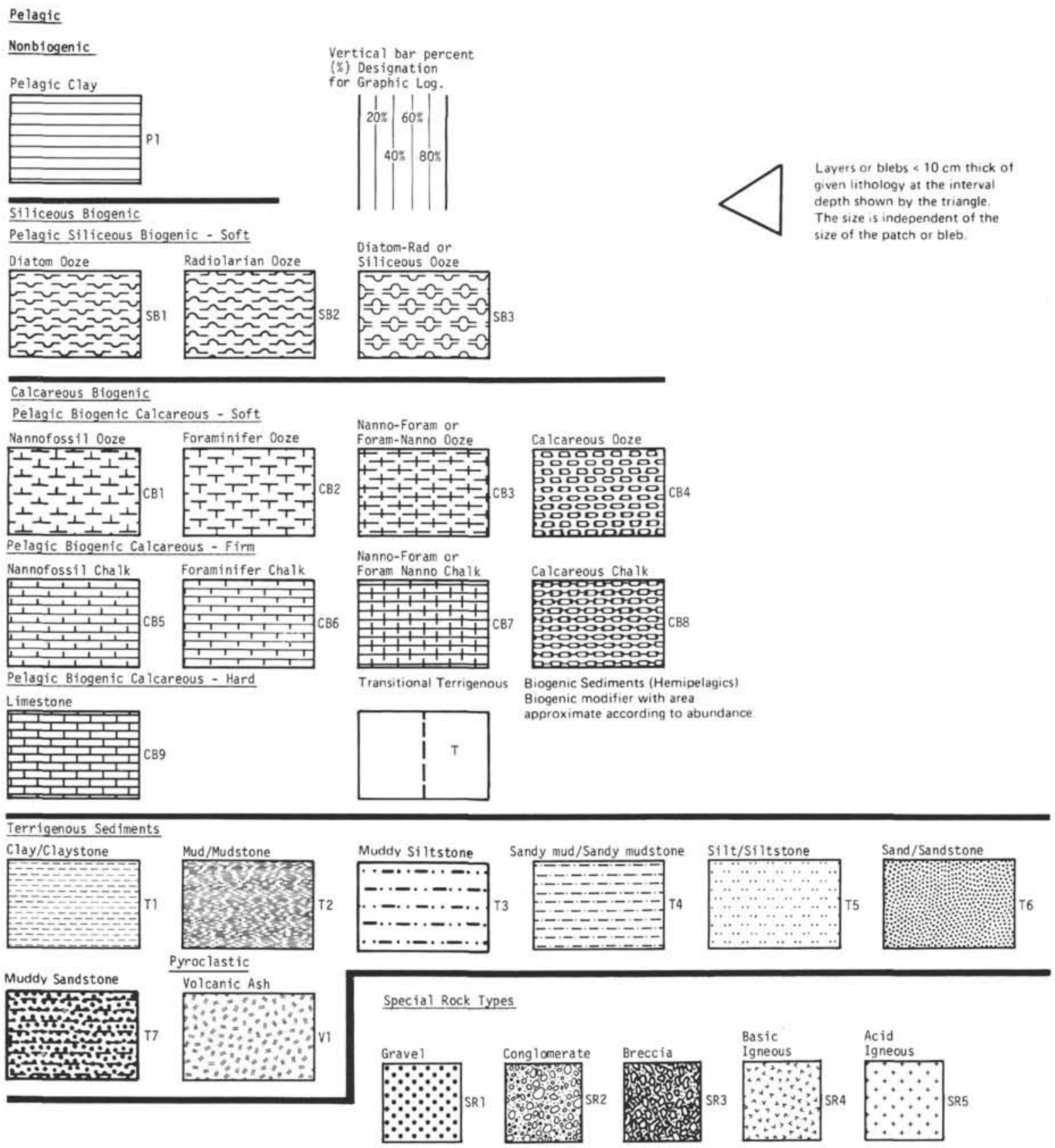

Figure 7. Symbols used in graphic lithology column of core description forms (sediment).

nodules, zeolites), fish debris, etc., become common $(>10 \%)$ in smear slides, indicating pelagic clay. Because the accumulation rates of pelagic clay and terrigenous sediments are very different, transitional deposits are exceptional.

2) Boundary of pelagic clay with siliceous-biogenicsediments is the point at which there is less than $30 \%$ siliceous remains.

3) Boundary of pelagic clay with calcareous-biogenic-sediment is uncommon. Generally this facies passes from pelagic clay through siliceous ooze to calcareous ooze, with one important exception: At the base of many oceanic sections, black, brown, or red clays occur directly on basalt, overlain by or grading up into calcareous sediments. Most of the basal clayey sediments are rich in iron, manganese, and other metallic trace elements. For proper identification they require more elaborate geochemical work than is available onboard ship. These sediments would be placed in the Special Rock category.

\section{Pelagic-Siliceous-Biogenic-Sediment}

Pelagic-siliceous-biogenic-sediment is distinguished from pelagic clay because the siliceous-biogenic-sediment has more than $30 \%$ siliceous microfossils. Siliceous-biogenic-sediments are distinguished from a cal- 


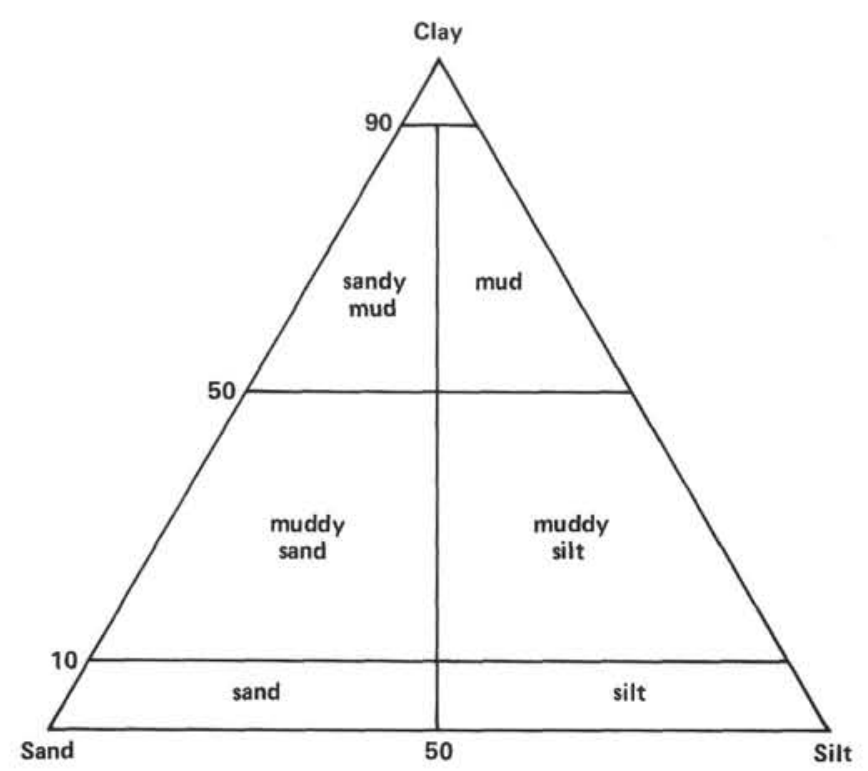

Figure 8. Terrigenous sediment classification on Leg 66 (used when siliceous components $<10 \%$, authigenic components $<10 \%$, and total terrigenous components $>30 \%$ ). careous category by a calcium carbonate content of less than $30 \%$. These sediment types were rarely encountered on Leg 66.

For a pelagic-biogenic-siliceous-sediment with $\sim 30$ $100 \%$ siliceous fossils, the following terminology is used: (1) soft: siliceous ooze (radiolarian ooze, diatomaceous ooze, etc. depending on the dominant fossil component); (2) hard: radiolarite, diatomite, chert, or porcellanite; (3) compositional qualifiers: Diatoms and radiolaria may be the principal components, thus one or two qualifiers may be used. The order of the two modifiers in the terms is dependent on the dominant fossil type. The most dominant component is listed last and the minor component listed first.

\section{Pelagic-Biogenic-Calcareous-Sediment}

Pelagic-calcareous-sediment is distinguished by a biogenic $\mathrm{CaCO}_{3}$ content in excess of $30 \%$. There are two classes: (1) pelagic-biogenic-calcareous-sediments which contain $60-100 \%$ biogenic $\mathrm{CaCO}_{3}$ and (2) transitionalbiogenic-calcareous-sediments which contain $30-60 \%$ $\mathrm{CaCO}_{3}$. These sediment types were rarely encountered on Leg 66.

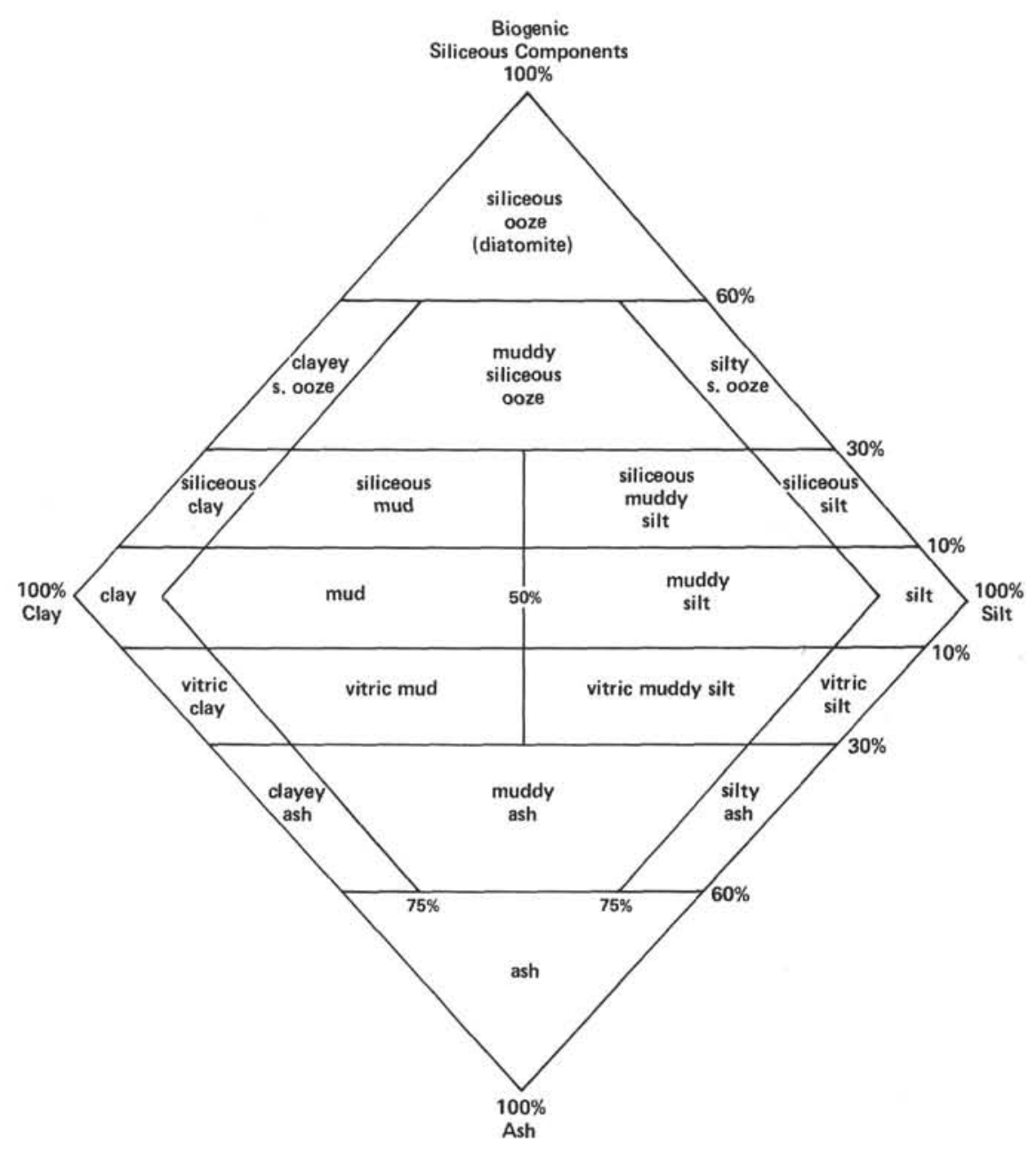

Figure 9. Hemipelagic sediment classification for use on Leg 66 (used when biogenic silica $>10 \%$, terrigenous component $>30 \%$, and total nonbiogenic component $>40 \%$ ). 
For the pelagic-biogenic-calcareous-sediment with 60 $100 \% \mathrm{CaCO}_{3}$ the following terminology is used: (1) soft: calcareous ooze; (2) firm: chalk; (3) hard and cemented: limestone; (4) compositional qualifiers: If nannofossils and foraminifers are the principal components, then one or two qualifiers may be used.

The transitional-biogenic-calcareous-sediments with $30-60 \% \mathrm{CaCO}_{3}$ are termed marl or marlstone, depending on whether they are soft or hard.

\section{Terrigenous Sediments}

Terrigenous sediments are distinguished by a terrigenous component in excess of $30 \%$ and by siliceous and authigenic components each less than $10 \%$. These are the most common sediment type encountered on Leg 66 .

Sediments in this category are subdivided into textural groups by smear slide estimation or grain size analysis on the basis of the relative proportions of sand, silt, and clay. The size limits are those defined by Wentworth (1922). Textural classification follows the triangular diagram (Fig. 8).

The transition between pelagic and terrigenous sediments is termed hemipelagic. This is the dominant type of sediment encountered during continental margin drilling. It is treated separately.

\section{Hemipelagic Sediments}

Hemipelagic sediments are distinguished by a terrigenous component in excess of $30 \%$, a total nonbiogenic component in excess of $40 \%$, and a biogenic silica content in excess of $10 \%$. Besides the terrigenous component, hemipelagic sediments are usually rich in biogenic silica (usually diatoms, because of coastal upwelling) and volcanic ash (predominantly along active margins). The classification of these sediments by dominant components can be represented by a pyramid in which the peak and each corner represent $100 \%$ of a specific component: $100 \%$ sand at the peak, $100 \%$ silt and $100 \%$ clay at diagonal corners of the base, and $100 \%$ biogenic silica and $100 \%$ ash at the other diagonal corners of the base.

The plane of the base of the pyramid (Fig. 9) shows the classification of sediments with a sand component of less than $10 \%$. Such sediments are the dominant type found on most continental margins, and thus the classification in Figure 8 is broadly applicable. The percentage of silt and clay used in the diagram (Fig. 9) refers only to terrigenous components. Authigenic minerals, ash, and biogenic particles are not included.

For biogenic opal contents greater than $10 \%$, the dominant siliceous biogenic component should be used in the name. We have used the term siliceous in the diagram (Fig. 9), but when other identifiable biogenic siliceous components dominate, the terms radiolarians, radiolarite, spicular, etc., may be used.

Components such as sand, diatoms, radiolarians, spicules, and ash may be used as qualifiers to the original sediment description if their abundance is $10-30 \%$ of the sediment. Within the textural group and the component group the modifiers are listed in order of increasing sedimentary abundance.

\section{Volcanogenic Sediments}

Pyroclastic rocks are described according to the textural and compositional scheme of Wentworth and Williams (1932). The textural groups are: $>32 \mathrm{~mm}-$ volcanic breccia, 32-4 mm-volcanic lapilli, and $<4 \mathrm{~mm}-$ volcanic ash (tuff when indurated). The composition of these pyroclastic rocks are described as vitric (glass), crystalline, or lithic.

Sediments rich in ash are described in the following manner:

\begin{tabular}{rll}
\hline$\%$ Ash & Soft Sediment & \multicolumn{1}{c}{ Indurated } \\
\hline $0-10$ & mud & mudstone \\
$10-30$ & vitric mud & vitric mudstone \\
$30-60$ & muddy ash & tuffite \\
$>60$ & ash & tuff \\
\hline \multicolumn{3}{c}{ Qualifiers }
\end{tabular}

In general, sediments containing various constituents in the $10-30 \%$ range may be identified in the name of sediment, e.g., vitric diatomaceous mud or vitric muddy diatomaceous ooze. If more than one such qualifier is used, they are listed in order of increasing abundance in the sediment.

\section{Igneous Rocks}

\section{Visual Core Description Forms}

All igneous rocks were split by rock saw into working and archive halves described and sampled onboard. Figure 10 shows a composite visual core description form used for the description of igneous rocks recovered on Leg 66. On this form, each section of a core is described under a set of five column headings: (1) piece number, (2) graphic representation, (3) orientation, (4) shipboard studies, and (5) alteration.

In the graphic representation column each piece is accurately drawn, and different features such as texture, glassy margins, or vesicles are coded according to the symbols in Figure 10. Two closely spaced horizontal lines in this column indicate the location of styrofoam spacers taped between pieces inside the liner. Each piece is numbered sequentially from the top of the section, beginning with the number 1 (piece number column). Pieces are labeled on the rounded surface rather than the flat slabbed face. Pieces which fit together before splitting were given the same number but are consecutively lettered $1 \mathrm{~A}, 1 \mathrm{~B}, 1 \mathrm{C}$, etc. Spacers were placed only between pieces which did not fit together; those pieces were given different numbers. In general, spacers may or may not indicate missing (not recovered) material between pieces. All cylindrical pieces longer than the diameter of the liner have arrows in the "orientation" column, indicating that top and bottom have not been reversed as a result of drilling and recovery. Arrows also appear on the labels of these pieces on both archive and working halves.

The column marked "Shipboard Studies" designates the location and the type of measurements made on a 


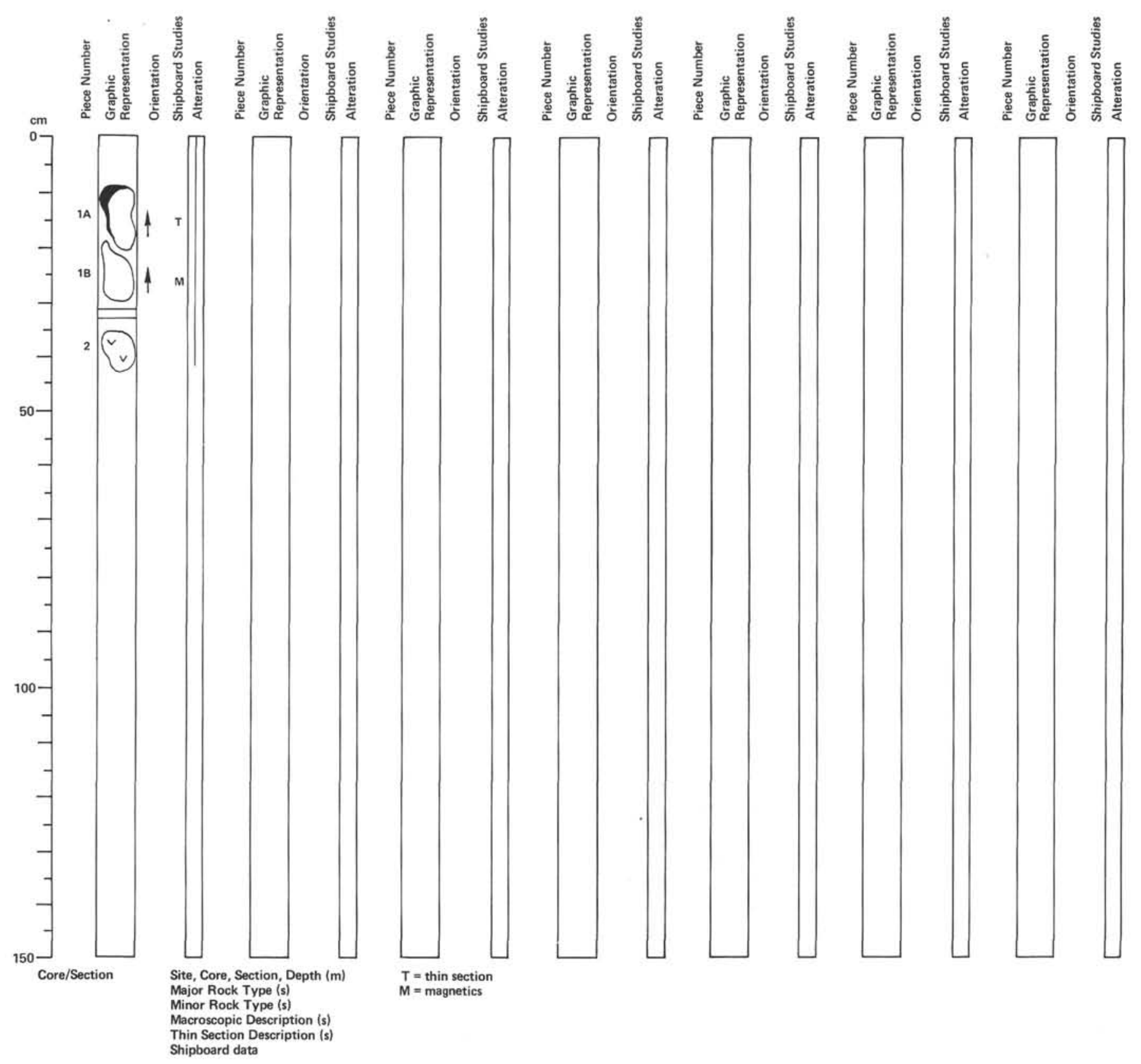

Figure 10. Visual core description form (igneous).

sample onboard. The column headed "Alteration" gives the degree of alteration, using the code given in Figure 11. Below each set of five descriptive columns is the designation for core and section for which these data apply.

Figure 9 gives the outline for core descriptions of igneous rocks in the right-hand margin of the visual core description form. If more than one core appears on the core form, these data are listed below the description of the first core, using the same format. As many cores as space allows are included on one visual core description form. When space for descriptions is inadequate, these data appear on the following or facing page. In no case does information from one core appear on successive core forms.
For each core, the core number, sections, and depth interval recovered are listed, followed by the major and minor rock types and a short description. Thin section data are tallied below this, followed by shipboard data.

\section{Classification of Igneous Rocks}

We informally classified igneous rocks from Leg 66 according to mineralogy and texture determined from visual inspection of hand specimens and thin sections.

\section{Photography}

Sets of color and black and white negatives of whole cores are available for consultation. In addition, negatives in black and white for closeup documentation of special structures are archived at DSDP. 


\section{REFERENCES}

Dickinson, W. R., 1971. Plate tectonics in geology history. Science, 174:107-113.

1973. Widths of modern arc-trench gaps proportional to past duration of igneous activity in associated magmatic arcs. $J$. Geophys. Res., 78:3376-3389.

Gealy, E. L., Winterer, E. L., and Moberly, R., 1971. Methods, conventions and general observations. In Winterer, E. L., Riedel, W. R., et al., Init. Repts. DSDP, 7, Pt. 1: Washington (U.S. Govt. Printing Office), 9-26.

Helsley, C. E., Nation, J. B., and Meyer, R. P., 1975. Seismic refraction observations in Southern Mexico. Am. Geophys. Union Trans., 56:452.

Hussong, D. M., Edwards, P. B., Johnson, S. H., et al., 1976. Crustal structure of the Peru-Chile Trench: $8^{\circ}-12^{\circ} \mathrm{S}$ latitude. In Sutton, C. H., Manghnani, M. H., and Moberly, R. (Eds.), The Geophysics of the Pacific Ocean Basin and Its Margin: American Geophysical Union Monograph 19: Washington (Am. Geophys. Union), pp. 71-86.

Karig, D. E., Ingle, J. C., Jr., et al., 1975. Init. Repts. DSDP, 30: Washington (U.S. Govt. Printing Office).

Karig, D. E., and Sharman, G. F., III, 1975. Subduction and accretion in trenches. Geol. Soc. Am. Bull., 86:377-389.
Mooney, W. M., Meyer, R. P., Helsley, C. E., et al., 1975. Refracted waves across a leading edge: Observations of Pacific shots in southern Mexico. Am. Geophys. Union Trans., 56:452.

Müller, G., and Gastner, M., 1971. The "Karbonate-Bomb," a simple devise for determination of the carbonate content in sediments, soils and other materials. Neues Jahrb. Mineral. Monatsh., 10: 466-469.

Seely, D. R., Vail, P. R., and Walton, G. G., 1974. Trench slope model. In Burk, C. A., and Drake, C. L. (Eds.), The Geology of Continental Margins: New York (Springer-Verlag), pp. 249-260.

Seyfert, C. K., 1969. Undeformed sediments in oceanic trenches with seafloor spreading. Nature, 222:70.

Shor, G. G., Jr., and Fisher, R. L., 1961. Middle America Trench: Seismic-refraction studies. Geol. Soc. Am. Bull., 72:721-730.

von Huene, R., 1972. Structure of the continental margin and tectonism at the eastern Aleutian Trench. Geol. Soc. Am. Bull., 83:3613-3626.

von Huene, R., Aubouin, J., and Azéma, J., 1980. The DSDP MidAmerica Trench transect off Guatemala. Geol. Soc. Am. Bull., 91:421-432.

Wentworth, C. K., 1922. A scale of grade and class terms of clastic sediments. J. Geol., 30:377.

Wentworth, C. K., and Williams, H., 1932. The classification and terminology of the pyroclastic rocks: Rept. Comm. Sedimentation, Bull. Nat. Res. Counc. U.S., 80:10-53.

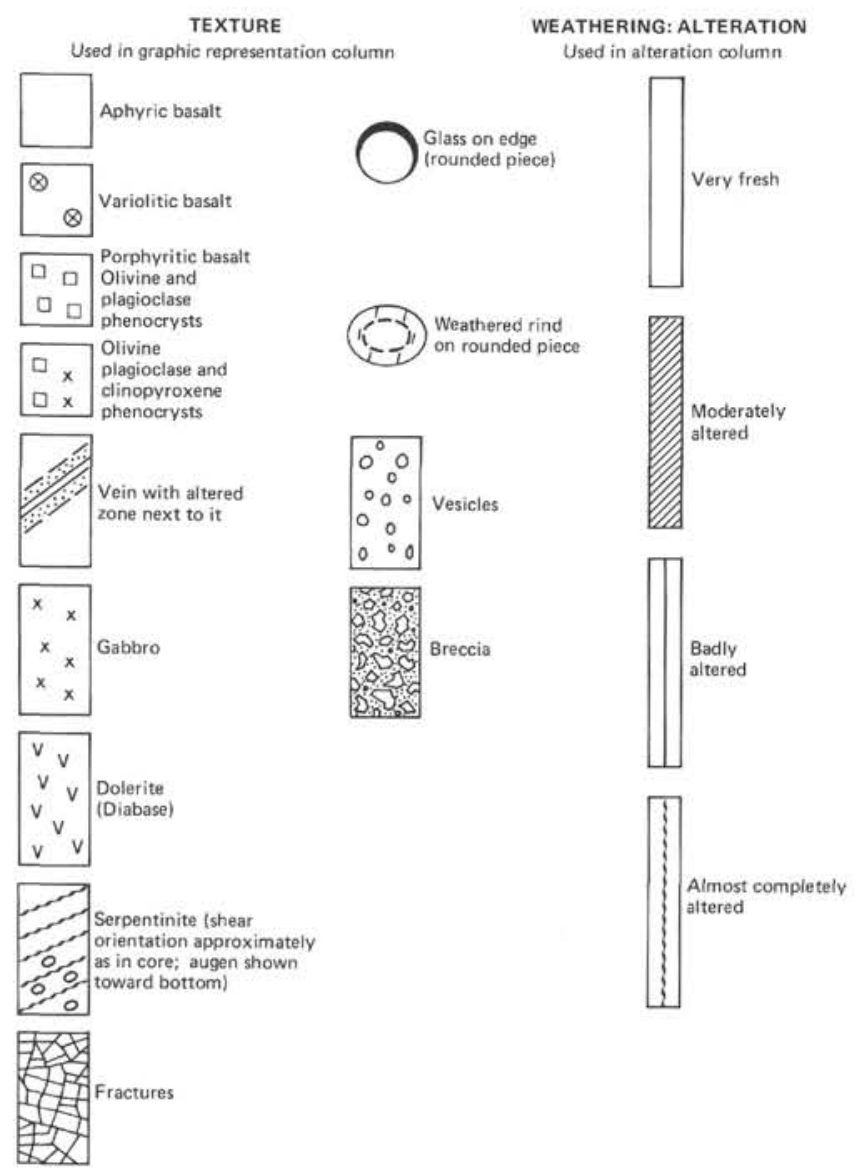

Figure 11. List of symbols for igneous rocks. 